\title{
Ferry Transport: \\ The Realm of Responsibility for Ferry Disasters in Developing Nations
}

Catherine T. Lawson, The University at Albany

Roberta E. Weisbrod, Partnership for Sustainable Ports

\begin{abstract}
Ferries, the safest form of transportation in North America and Europe, can be the agents of catastrophe in some developing nations. Over the past decades there have been numerous incidents in which hundreds have died. The international ferry community, under the leadership of Interferry and the Worldwide Ferry Safety Association, working with IMO support, has embarked on a comprehensive 10-year plan to reduce ferry fatalities by 90 percent. This article describes the first research task needed to achieve the ferry safety goal of devising a framework to determine the responsible parties for ferry safety across the full social fabric, including ferry owners, local and national ferry authorities, national trade associations and international business and regulatory associations. This framework is intended to inform and be used as a guide to mobilize the relevant sectors of society to achieve reduction in ferry fatalities.
\end{abstract}

\section{Introduction}

Ferries, the safest form of transportation in North America and Europe, can be the agents of catastrophe in some developing nations. Over the past decades 
there have been numerous incidents in which hundreds have died. Even in the first few years of the 21st century there have been, on average, over 1,000 fatalities per year. In most of the nations with the poorest safety records (e.g., Bangladesh and Somalia), ferry travel is not discretionary. Travel is not primarily for recreation but is virtually the only way to pursue work and maintain social connections. The economic development of these nations is stymied by the lack of reliable mobility. In addition, the loss of life and the human tragedy disproportionately impacts those in their prime.

The international ferry community, under the leadership of Interferry, working with International Maritime Organization (IMO) support, has embarked on a comprehensive 10-year plan to reduce ferry fatalities by 90 percent. This article describes the first research task needed to achieve the ferry safety goal of devising a framework to determine the parties responsible for ferry safety across the full social fabric, including ferry owners, local and national ferry authorities, national trade associations, and international business and regulatory associations. This framework is intended to inform and be used as a guide to mobilize the relevant sectors of society to achieve reduction in ferry fatalities.

\section{Background}

Over the past several decades, the number and frequency of large-scale fatalities from ferry incidents in emerging nations have been appalling. This trend has continued to the present time, with over 4,000 people reported to have died in ferry accidents between January 2000 and May 2004 alone. (Note that the fatality statistics are based on bodies recovered; very often there are a larger number of persons listed as "missing." In addition, precise documentation is not always possible because the actual number of passengers is frequently unknown. See Table 1).

\section{Context of Ferry Fatalities}

Compared to other modes within Bangladesh, the rate of ferry fatalities is comparable to road transport fatalities. Four thousand people die annually in road accidents. ${ }^{1}$ Compared to the developed world-for example, the United States-road fatalities in Bangladesh have a high convergence; in the United States there are close to 40,000 fatalities annually-10-fold the number of fatalities in Bangladesh, a nation with about 45 percent of the U.S. population. (The differential reflects the 


\section{Table 1. New Millennia Ferry Fatalities (Documented)}

\begin{tabular}{rlrll}
\multicolumn{1}{c}{ Date } & Nation & $\begin{array}{c}\text { Number of } \\
\text { Fatalities }\end{array}$ & Cause & Source \\
\hline $5 / 24 / 04$ & Bangladesh & $>150$ & Weather & Lloyd's List (2004) \\
\hline $3 / 20 / 04$ & Somalia & 100 & Collision & IOL (2004) \\
\hline $3 / 20 / 04$ & Indonesia & $>200$ & Rough seas & ABC News (2004) \\
\hline $3 / 19 / 04$ & Maldives & 17 & Overcrowding & BBC News (2004b) \\
\hline $3 / 10 / 04$ & Madagascar & 100 & Cyclone & BBC News (2004a) \\
\hline $2 / 22 / 04$ & Pakistan & $6-12$ & Capsize & BBC News (2004c) \\
\hline $11 / 03$ & Congo & 163 & Collision & Henry (2004); BBC News (2003C) \\
\hline $11 / 03$ & Zambia & 40 & Storm & Henry (2004); BBC News (2003c) \\
\hline $10 / 03$ & United States (NYC) & 11 & Illness & Kennedy and Flynn (2003) \\
\hline $7 / 03$ & Bangladesh & 400 & Whirlpool & Tribune (2003); BBC News (2003a) \\
\hline $4 / 03$ & Bangladesh & $>280$ & (4 incidents) & BBC (2003b) \\
\hline $1 / 03$ & Tanzania & 40 & Capsize & BBC News (2003C) \\
\hline $1 / 03$ & Somalia & 80 & Rickety boat & BBC News (2003C) \\
\hline $11 / 02$ & Somalia & 30 & Lost power & BBC News (2003C) \\
\hline $10 / 02$ & Senegal & 1800 & Storm & Henry (2004); BBC News (2003C) \\
\hline $5 / 02$ & Bangladesh & 370 & Storm & World Travel Watch (2002) \\
\hline N/A & Indonesia & 60 & N/A & Henry (2004) \\
\hline $12 / 29 / 00$ & Bangladesh & 200 & Collision & Priyangika (2001) \\
\hline
\end{tabular}

very low rate of vehicle ownership, counterbalanced by the high rate of incidence of road fatalities and the high rate of fatalities to casualties. ${ }^{2}$ )

When the number of ferry fatalities is compared to road fatalities in the developed world, the issue of ferry fatalities is stark. In the developed world, the number and incidence of road fatalities are high, whereas ferry fatalities are virtually nil. For example, the U.S. ferry system transports 200 million passengers annually ( $h t t p: / /$ www.oduport.org/Ferry.htm); the Bangladesh system transports approximately 40 million (http://nation.ittefaq.com/artman/exec/view.cgi/18/10609). In Bangladesh, there were over 1,000 fatalities annually; in the United States, there were virtually no fatalities between 1904 (the General Slocum ferry incident) and 2003 (the Staten Island ferry incident).

\section{Why Study and Seek to Address Ferry Fatalities?}

Although for Bangladesh the ferry and road transport accident statistics are roughly comparable, ferry transport is important because, relatively, ferry systems are more environmentally sustainable and require far lower capital investment for 
expansion and improvement and they have multiple values for economic development.

In general, ferry transport is often a critical element of economic development for many nations because of their fundamental reliance on ferries for the transport of people and goods-hence the critical importance of ferries to jobs and trade as a catalyst of economic growth (Weisbrod and Lawson 2003a). In many of the nations where the high fatality incidents occur, ferry transport is essential to the lives of the local populations. Geographic features, both physical and political, precondition the need for ferry transport for nations with island archipelagos, unbridgeable straits, riverine deltas, poor road transport, or a combination of these geographic features. With transportation the basis of economic development and ferry systems the major component of transportation systems, the lack of safety is economically devastating.

Creating a safe and reliable ferry system is also crucial to these nations' sustainable future. Ferries for transport of people and goods, notwithstanding the fact that they produce emissions, have a lower environmental impact than other forms of transportation. In terms of planning for the future, the highly developed and urbanized world has concluded that more waterborne transport of people and freight is sustainable, with both the European Union and the United States actively encouraging its use, particularly for freight.

The problem of ferry safety in the developing world will not go away on its own. The mindless loss of human life must be curbed-and can be. The international maritime and ferry communities stand ready to offer their assistance and capacity-building know-how. Foremost in this endeavor is the international ferry organization, Interferry.

Interferry is a trade association representing the worldwide ferry industry. Its participation is key to solving the ferry safety catastrophe in developing nations. In existence for almost 30 years, the organization has over 160 member companies from 22 countries and is actively engaged in expansion. Interferry participates with nongovernmental organization (NGO) status in IMO activities and is a member of the Maritime Safety Committee. As such, Interferry can reach out to developing nations on a collegial basis. Trade associations can be an effective vehicle for positive change, for both the industry and for government, as our research on the role of the transportation trade associations in homeland security has demonstrated (Weisbrod and Lawson 2003b). 
Members of Interferry formed a nonprofit organization, the Worldwide Ferry Safety Association (WFSA), a registered 501C3. The organization is led by a board of directors, which includes the CEO of Interferry, Len Roueche, and one of the authors of this paper, Roberta Weisbrod. An advisory board is in formation.

Interferry/WFSA and IMO have initiated a 10-year plan with the goal of reducing fatalities by 90 percent. The first steps are: (1) identification of the nature of the safety problem in ferry transport through root cause analysis; (2) comprehending responsibility for ferry safety, in order to know with whom to work and how to work with them; and (3) creation and analysis of a definitive 25-year database for ferry fatalities, in order to know what major factors are precipitating and contributing to fatalities, so that a practical and effective approach may be devised. A pilot project will be planned by a Bangladesh-based ferry safety working group in late 2005-early 2006.

\section{A Framework for Determining Responsibility}

Essential to the success of the endeavor is the development of a framework capable of examining how responsibility is distributed and how it can be leveraged. One of the most famous ferry tragedies was the General Slocum (in which over 1,000 people died on a sunny day in sight of land in New York City, in 1904) (O'Donnell 2003). Previous work used the sinking of the General Slocum as a platform for understanding the realm of responsibility (Weisbrod et al. 2005). Based on that analysis, questions to be asked include not only what entities control creation of policy, establishment of regulations, application of technology, inspections, enforcement of regulations, training, training standards, search and rescue, and reporting and analysis of incidents, but also what other entities, such as the press, citizens groups and local governments without statutory authority, can raise the standards and how can the governmental and nongovernmental sectors create the feedback loop on continuous improvement? These questions illustrate the complex reality of controlling ferry safety.

The review of the incident in Bangladesh in 2004 is used to develop a model to determine what entities in the public, private and nongovernmental sectors are responsible for which aspects of ferry safety and how they do and do not exercise their responsibility. Other recent and highly documented ferry casualties include the capsizing of the Baltimore water taxi in 2004 (Brumfield 2004); the Staten Island ferry collision of 2003 (Weisbrod and Lawson 2004); the sinking of the vehi- 
cle passenger (Ro-Pax) ferry Estonia in 1994 (Langewiesche 2004); and the capsize after debarkation of the Ro-Pax Herald of Free Enterprise in 1987 (Crainer 1993).

\section{Bangladesh: Exploring the Realm of Responsibility Role of Ferries}

Bangladesh is a nation of over 130 million people living on a coastal river delta, interspersed with 250 north-south rivers. Ferries, of which there are purported to be 20,000 , are a major mode of transport for most of the population (Reuters 2004). The ferry fleet is divided into two distinct types of services and vessel types: (1) ferries used for river crossings that are designed to carry cars and trucks, under the control of the Inland River Authority; these ferries rarely become involved in accidents, and (2) ferries that travel longer distances, leaving from Dhaka to travel to the islands and delta communities, which are more likely to be involved in catastrophic accidents.

\section{Record of Ferry Accidents}

In Bangladesh, every year there are many ferry accidents in which hundreds of people die. According to our records, between April 2003 (Lawson 2003) and July 2003 (BBC News 2003a) alone, over 1,200 people died in six separate incidents. Tracking the number of fatalities is difficult because the number of passengers is usually not known and multiple accidents occur at similar times and places. At the time of a recent ferry disaster in May 2004, when over 150 people died (Lloyd's List 2004), officials from the Inland Water Transport Authority said that over 1,000 people die in ferry accidents each year and more are counted missing (Reuters 2004). Accident reporting is unreliable at present and makes meaningful analysis difficult.

\section{Disaster Factors}

The precipitating factors tend to be weather-related. The storms of May and June are most virulent. The Ministry of Shipping addressed this issue by forbidding ferries from going out during the hours of 3:00 and 8:00 PM during the monsoon, a ban that was subsequently rescinded when ferry operators protested (BBC News 2003b).

One major contributing factor seems to be massive overcrowding. The number of passengers is never known, but the overcrowding is surmised from the number of fatalities and survivors. The Minister of Shipping has stated that "ultimately, it 
was up to passengers to decide not to board ferries that are too crowded" (Lawson 2003). Related to the overcrowding issue is the governmental mandate to cap fares. If ferry operators are unable to raise revenues by increasing fares, they are likely to increase revenues simply by allowing many more passengers on the vessel.

Stowage of cargo on the deck is another factor, creating top-heavy imbalance and contributing to capsizing, especially in rough weather. Substandard vessels are also a significant contributing factor; some have been purchased after long-term use elsewhere. Officials from the Inland Water Transport Authority said that over 20,000 vessels are in service, but only 8,000 are registered and, of those, only about 20 percent were certified as fit to operate (Reuters 2004).

\section{Structure of Responsibility}

The portfolio of the Minister of Shipping, one of 24 cabinet ministers, includes design of vessels as well as enforcement of laws and regulations pertaining to shipping. The minister has stated for the record that passengers have a responsibility not to board overcrowded vessels; during April 2003 the ministry ran public service announcements not to travel on overcrowded vessels during the stormy season which begins in April/May (BBC News 2003b).

The Inland Water Transport Authority, established in 1958, develops and regulates the inland water network. With respect to inland development, the agency undertakes planning and dredging projects. Its regulatory role is limited to the commercial aspects-overseeing ferry fares and timetables. Although the Inland Water Transport Authority apparently has no regulatory authority on ferry safety, it does seem to be documenting incidents.

\section{Public and Private Sector Operators}

Of the more than 20,000 ferries in Bangladesh, 3,000 are state-owned and more than 4,000 are privately-owned. Some of this uncertainty in numbers of ferries can be explained by the fact that only 8,000 ferries actually are registered (Reuters 2004).

\section{Labor}

The relevant labor federations include the Noujan [river vessels] Workers' Federation, which operates on 4,000 private river ferries. In 2002 the workers went on a strike over safety-but their issue was piracy, not operational safety (Worldwide Socialist News 2002). 


\section{Ferryboat Operators}

Ferryboat operators exercised their right of protest in April 2003 to overturn a government-imposed ban on night travel (BBC News 2003b). The Ministry of Shipping had instituted a ban on travel between 3 and 8 PM during monsoon season in early 2003 and rescinded the ban when "ferry owners promised not to operate their vessels in inclement weather and to follow safety regulations" (Sydney Morning Herald 2003). Note that the protest and its results were reported in July 2003 in an article headlined "600 feared dead in a night voyage during monsoon season," which the ban was intended to avoid and the ferry owners' promises would have prevented.

\section{Local Government}

To date, the local government has not played a role.

\section{International Organizations}

The IMO, a United Nations agency, is concerned with safety for international shipping and the prevention of marine pollution. The agency is responsible for adopting rules for international maritime issues, which the 164 member nations implement. Ferries that are in domestic trade only are not considered part of its portfolio. However, the current leadership, as well as the previous one, is committed (as are members) to addressing the issue of ferry safety. As Efthimios Mitropooulos, the secretary-general has said (Maritime News 2004):

It is essential that we find way of addressing the question of safety standards aboard non-convention ships [i.e., ships that are not subject to IMO regulations]. The tragic ferry accidents in the Philippines and the Maldives this year have highlighted how devastating these incidents can be in terms of loss of life. IMO has already promoted the development, adoption and implementation of safety codes for non-convention vessels in Asia and the Pacific, Africa, the Caribbean and the Mediterranean and will continue to explore initiatives to assist countries in avoiding these tragedies in the future.

Bangladesh is a member of the IMO and also a member of the Maritime Safety Committee (MSC). A Bangladesh citizen, Captain Moin Uddin Ahmed, is the head of the Asia Pacific Section of the Technical Cooperation Division of the IMO ( $\mathrm{L}$. Roueche, personal communication 2005).

Table 2 highlights the important aspects of ferry accident prevention, including the role and effectiveness of regulation, vessel design and operations and the initial 
response. Table 3 addresses postevent issues: investigation, documentation of the accident, sanctions, insurance, and victim support.

\section{Table 2. Prevention and Response for Ferry Safety in Developing Countries}

\begin{tabular}{|c|c|}
\hline Function & Issues/Area of Inquiry \\
\hline Prevention & \\
\hline Regulatory Approach & $\begin{array}{l}\text { Are the regulations adequate to the conditions? } \\
\text { How does the rule making take place? } \\
\text { How are rules communicated? } \\
\text { How are regulations enforced? } \\
\text { Is there any oversight in the implementation of the regulations? }\end{array}$ \\
\hline Vessel Design & $\begin{array}{l}\text { Are vessels designed properly for their purpose? } \\
\text { What proportion of the fleet of vessels is certified? } \\
\text { Are there penalties/obstacles for certification? } \\
\text { Are these noncertified vessels long-after, after-market vessels? } \\
\text { Are there penalties for noncertification? } \\
\text { Is there a difference with respect to accident rates for long-after, } \\
\text { after-market vessels? } \\
\text { What and how rigorous is the certification process? } \\
\text { What is the relationship between ferry fatalities and vessel certifica- } \\
\text { tion? } \\
\text { Are the vessels inappropriate or inadequately maintained and/or } \\
\text { improperly operated? }\end{array}$ \\
\hline Operational Standard & $\begin{array}{l}\text { What is the accident record differential between certified/noncerti- } \\
\text { fied vessels with respect to operating standards? } \\
\text { What is the accident record differential between vessels that are } \\
\text { publicly or privately owned? } \\
\text { Are there differences with respect to routes and type of service } \\
\text { between public and private operations? } \\
\text { How can registration/certification be encouraged by the industry, } \\
\text { local government, or citizens groups? }\end{array}$ \\
\hline Response & $\begin{array}{l}\text { What type of training and drills are available for private or public } \\
\text { crews? } \\
\text { Is there a relationship between the record of training and drills and } \\
\text { ferry fatalities? } \\
\text { Is there a formal system in place for search and rescues? } \\
\text { Have "safe havens" been identified in event of major storm and/or } \\
\text { vessel damage? }\end{array}$ \\
\hline
\end{tabular}




\section{Table 3. Post-Event Responsibilities for Ferry Safety in Developing Countries}

Function

Investigation
Issues/Area of Inquiry

What agency investigates ferry accidents?

How are involved parties informed of results?

Are accident investigation reports disseminated in a timely and well-publicized fashion so that operators and regulators can learn from them?
Documentation of accidents
Where, who, how and what if there isn't any?

Is there an active press to track and continually publicize incidents and the role of government and industry in implementing safe conditions on ferries?
Sanctions
What is the record of sanctions to those who violate the safety rules?

Consider that the innate sanction of loss of asset for owners is not a feedback mechanism because the vessel is already depreciated.

What would be effective? available? Are liability coverage provisions enforced?

\section{Effecting Positive Change}

One approach to establishing a positive model for ferry safety is to tie international aid for the purposes of vessel purchase to improved operational oversight. The Danish aid organization Danida has had a history of assisting the ferry sector of Bangladesh, working with the national government and coordinating its activities with the World Bank (Underenrigmisteriet undated). Since 1981, Danida has assisted the ferry sector by delivering several ferries, financing local construction of ferries (with main components from Denmark), and helping to construct and rehabilitate docks. Technical assistance and training have been part of the package. In 2002, Danida announced that relations with the Shipping Ministry were such that cooperation was not possible and rescinded its commitment for renovation 
of ferries for the locality of Aricha (a port on the Ganges) and related activities. Danida is assisting the roads and highways department of the Communications Ministry in the construction of ferries and landing pontoons by a privately-owned Bangladeshi shipyard (Bangladesh Observer 2004).

Nations also can offer assistance by providing a framework of lifesaving standards for ferries. The U.S. Coast Guard Navigation and Vessel Inspection Circular (NVIC) 1-97 for Shipboard Safety Management and Contingency Planning for Passenger Vessels (www.uscg.mil/hq/nvic/1-97/n1-97.htm) is sufficiently flexible to be adaptable by ferry operators in a wide variety of circumstances of geography and use. The NVIC follows a "keep it simple" philosophy that makes it especially useful.

Although not proactive with respect to preventing accidents, the International Red Cross assists with rescue efforts and provides trauma counseling to survivors and the bereaved (BBC News 2003b).

After the issues presented in Tables 2 and 3 are examined, there is still a question of how best to promote a vector of change. The goal of reducing ferry fatalities by 90 percent over 10 years will not be accomplished with data collection and rootcause analysis alone. A well-funded program of projects developed on the basis of analysis is needed to determine what will make a difference. What steps, organizations, and/or stakeholders can be brought to bear?

Like Bangladesh's successful program for infant mortality reduction, this project will have to go beyond traditional central government activities (World Bank 2003). It will need full, active engagement of multiple sectors of society, including the press, local government, labor, trade associations and the international community. State or provincial government can help solve problems by demonstrating innovative solutions. Local government, through its control of land use for ferry landings, can control the industry.

Trade associations offer a unique opportunity to effect change. An investigation into the role of the transportation trade associations in homeland security revealed that roughly half the associations representing liquid bulk carriers prepared model security plans, coordinated with agency guidance, for their member companies. A benefit for the companies was agency endorsement of the plans, customer appreciation, and a greater ease of implementation (Weisbrod and Lawson 2003b).

Employees can be at the front line in pushing for safety. Workers' lives are at stake; they understand the issues from daily exposure to unsafe conditions. Unions could be an untapped resource for safety issues. It may depend on the structure of the 
labor federations and unions. Are their members working for both the private and public companies? Are the unions capable of protecting their members and, if so, can they be successfully integrated into effecting change?

A final opportunity may be the rapid adoption of communication technologies, such as cell phones and other wireless devices. As developing nations expand their use of wireless technologies, citizens will be able to report unsafe situations (Arnold 2001). These communications could make enforcement easier and also serve as receivers for weather information or other news that could influence the safety of ferry sailings.

\section{Concluding Remarks}

Reaching the goal of reducing ferry accidents in developing countries by 90 percent in 10 years will take a serious effort by all parties. By systematically examining the evidence and establishing and allocating responsibilities, the partners in ferry safety can make progress on a number of fronts. Concentrating on Bangladesh has immediate benefits. If current efforts produce successful experiences, lessons learned can provide transferable strategies for other countries with similar challenges. What can we do to reduce ferry fatalities? What will be the driver for change in the developing nations? What sectors of society can be mobilized to work with governmental leadership and how can they best exert their locus of responsibility?

\section{End Notes}

${ }^{1}$ In terms of incidence of fatalities, road transport accounts for approximately four times the number of ferry fatalities. Road transport, however, accounts for 72 percent of the 73 billion passenger kilometers $(\mathrm{km})$ traveled, while ferry transport accounts for 14 percent (http://www.adb.org/Documents/TARs/BAN/R18300.pdf). By that measure, road transport, at fivefold the passenger $\mathrm{km}$ traveled but with fourfold the fatalities, has a somewhat lower incidence rate.

${ }^{2}$ In 2000, there were 550,000 motorized vehicles in Bangladesh (http://w3.whosea. org/EN/Section1243/Section1310/Section1343/Section1344/Section1836/Section1837_8165.htm), compared to 213 million in the United States. The incidence rate is between 70 and 160 per 10,000 vehicles versus 2 in the United States. Also, an additional 6,000 casualties required hospitalization; in the United States, for every fatality there are 13 casualties requiring hospitalization, reflecting differences in the emergency medical care. 


\section{References}

ABC News. 2004. Indonesian ferry sinks. March 20. www.abc.net.au.

Arnold, W. 2001. Cell Phones for the world's poor: Hook up rural Asia, some say, and ease poverty. New York Times. January 19.

Bangladesh Observer. 2004. Danish envoy rejects press report: Cooperation with Shipping Ministry won't be restored. www.bangladeshobserveronline.com/ new2004/04/26/economic.htm.

BBC News. 2003a. Ferry disaster claims hundreds. http://news.bbc.co.uk/go/pr/fr//2/hi/south_asia/3051683.stm.

BBC News. 2003b. Over 100 dead as ferries capsize. April 2003. http://news.bbc. co.uk/go/pr/fr/-/1/hi/world/south_asia/2966277.stm.

BBC News. 2004a. Ferry lost in Madagascar cyclone. March 10, 2004. htpp://news. bbc.co.uk.

BCC News. 2004b. Maldives ferry sinks. March 19, 2004. htpp:||news.bbc.co.uk.

BBC News. 2004c. Pakistan ferry capsizes. February 22, 2004. htpp:||news.bbc. co.uk.

Brumfield, S. 2004. Baltimore water taxi capsizes, killing at least 1. March 7, 2004. Washington Times. http://washingtontimes.com/national/20040307-1206295731r.htm.

Crainer, S. 1993. Zeebrugge: Learning from disaster-Lessons in corporate responsibility. London: Herald Charitable Trust.

Henry, J. S. 2004. Third (and first) world ferry accidents-"Tragic misfortunes" or predictable consequences? SubmergingMarkets.Com White Paper.

IOL. 2004. Somali ferry sinks. April 2. www.iol.co.za.

Kennedy, R., and K. Flynn. 2003. The ferry crash at the helm, a pilot's uneventful routine ends in a fatal catastrophe. New York Times. October 16.

Langewiesche, W. 2004. The outlaw sea: A world of freedom, chaos and crime. New York, NY: North Point Press.

Lawson, A. 2003. Bangladesh minister holds firm. BBC News (July 16, 2003). http:// news.bbc.co.uk/go/pr/fr/-/1/hi/world/south_asia/3070039.stm. 
Lloyd's List. 2004. Bangladesh in the news again. May 24, 2004.

Mitropooulos, E. 2004. Challenges facing the IMO. Maritime News. June 2004.

O'Donnell, E. T. 2003. Ship ablaze: The tragedy of the steamboat General Slocum. New York: Broadway Books.

Priyangika, N. 2001. Bangladesh's worst ferry disaster claims nearly 200 lives. World Socialist Web site. January. http://www.wsws.org/articles/2001/jan2001/bangj05.shtml.

Reuters AlertNew.org. May 2004. http://www.alertnet.org/.

Sydney Morning Herald. 2003. 600 feared dead in ferry disaster. (July 9, 2003). www. smh.com.au/articles/2003/07/09/1057430252328.html.

Tribune. 2003. Ferry sinks in Bangladesh, 400 feared dead. July 9. http://www.tribuneindia.com/2003/20030710/world.htm.

Underenrigmisteriet (the Danish Government website-no date available) on Danida (international aid organization) and the Bangladesh-River Transport Sector. http://www.um.dk/Publikationer/Danida/English/CountriesAndRegions/Bangladesh/Strategy/bangladesh.6.2.3.asp.

Weisbrod, R. E., and C. T. Lawson. 2003a. Ferry systems: Planning for the revitalization of U.S. cities. Journal of Urban Technology 10 (2): 47-68.

Weisbrod, R. E., and C. T. Lawson. 2003b. Homeland security and the bulk liquid supply chain: Strengthening the role of the private sector. Presented at the Transportation Research Board (TRB) Annual Meeting, January 9-13, 2005, in Washington, D. C. Available on CD ROM.

Weisbrod, R. E., and C. T. Lawson. 2004. Ferry systems: Planning for the revitalization of U.S. cities-The role of safety. Presented at the Transportation Research Board (TRB) Annual Meeting, January 9-13, 2005, in Washington, D. C. Available on CD ROM.

Weisbrod, R. E., C. T. Lawson and L. Roueche. 2005. Ferry transport: The realm of responsibility for disasters in developing nations. Presented at the Transportation Research Board (TRB) Annual Meeting, January 9-13, 2005, in Washington, D. C. Available on CD ROM. 
World Bank. 2003. Annual Report on Bangladesh. http://Inweb18.worldbank.org/ lo\%20web\%20sites/bangladesh\%20web.nsf/0/dc5134fc4dabb9b985256b05007 c6629?OpenDocument.

Worldwide Socialist News. 2002. Bangladesh ferry workers strike over safety. June. www.wsws.org/articles/2002/jun2002/lab-j15_prn.shtml.

World Travel Watch. 2002. May 13. http://www.worldtravelwatch.com/ archives/2002/05/bangladesh.shtml.

\section{About the Authors}

CAtherine T. LAWson (lawsonc@albany.edu) is an assistant professor in the Department of Geography \& Planning at the University at Albany in New York. She received her master's degrees in urban and regional planning and in applied economics and her doctor's degree in urban studies/regional science from Portland State University in Oregon. Her research interests include water-related transport (passenger and freight), travel behavior, and archived intelligent transportation systems (ITS) data visualization.

Roberta E. WeISBROD (weisbrod@sustainableports.com) is the director of Partnership for Sustainable Ports LLP, a business dedicated to improving the public and private benefits of maritime transportation. Her research interests include waterrelated transportation (passenger and freight), environmentally sound urban freight transportation, and waterfront development. She was Director for Sustainable Transportation at INFORM, an environmental organization; Director for Port and Intermodal Planning at the New York City Economic Development Corporation; and special assistant to the Commissioner for Harbor Environmental Issues at the New York State Department of Environmental Conservation. She has a Ph.D. in biochemistry from Cornell University Medical College. She is the cofounder with Len Roueche of the Worldwide Ferry Safety Association. 